\title{
Dissipation Dynamics of Certain Pesticides on Open Field and Poly House Conditions
}

\author{
Shashi Vemuri, K.Kavitha, S.Swarupa \\ All India Network Project on Pesticide Residues \\ Prof.Jayashankar Telangana State Agricultural University \\ EEI Premises, Rajendranagar, Hyderabad \\ Sash_3156@yahoo.co.in
}

\begin{abstract}
Studies were undertaken to establish dissipation dynamics of commonly used insecticides at recommended dose both in open field and poly house situations to assess the differences in rate of dissipation, and also to recommend Pre-Harvest Intervals based on MRLs established by CAC and FSSAI. Utilizing dimethoate 30\%EC@300 g a.i.ha ${ }^{-1}$, $\lambda$-cyhalothrin 5\% EC @ 15 g a.i.ha ${ }^{-1}$, phosalone 35\% EC @ 450 g a.i. $h a^{-1}$, flubendiamide 20\%WG, profenophos 50\%EC @ $500 \mathrm{~g}$ a.i. ha ${ }^{-1}$ sprays and capsicum samples collected at regular intervals were analyzed for residues. The dissipation pattern of insecticides varied in poly houses and open fields, where initial deposits were comparatively higher and dissipated slowly in poly houses, Dimethoate initial deposits $\left(0.19 \mathrm{mg} \mathrm{kg}^{-1}\right)$ are less than FSSAI MRL of $2 \mathrm{mg} \mathrm{kg}$, hence a PHI of 1 day can be recommended. In case of poly house, initial deposit of $2.42 \mathrm{mg} \mathrm{kg}^{-1}$ was observed and hence a safe waiting period of 7 days can be recommended since FSSAI MRL is $2 \mathrm{mg} \mathrm{kg}^{-1}$. As no MRLs are available for lambdacyhalothrin, PHI of 5 can be recommended as residues dissipated to BDL, though the initial residues are 0.16 $m g \mathrm{~kg}^{-1}$ and $0.37 \mathrm{mg} \mathrm{kg}^{-1}$ in open fields and poly house, respectively, due to very less field dose. In case of phosalone, initial deposits of $5.35 \mathrm{mg} \mathrm{kg}^{-1}$ were recorded in poly house and hence a safe waiting period of 10 days should be recommended since FSSAI MRL is $1 \mathrm{mg} \mathrm{kg}^{-1}$. Spray of flubendiamide at recommended dose resulted in $1.19 \mathrm{mg} \mathrm{kg}^{-1}$ initial deposit which dissipated to BDL by $15^{\text {th }}$ day in poly house. However, as the Codex MRL is $2 \mathrm{mg} \mathrm{kg}^{-1}$, a PHI of 1 day is ideal for food safety. As per the Insecticide Act, 1969, profenofos is not recommended for use, but when sprayed at farmer's dose on capsicum, $3.71 \mathrm{mg} \mathrm{kg}^{-1}$ and $2.24 \mathrm{mg} \mathrm{kg}^{-1} \mathrm{initial}$ deposits were recorded in poly house and open field, respectively. Codex suggests MRL as $10 \mathrm{mg} \mathrm{kg}^{-1}$, hence it can be concluded that profenofos application does not leave residues above MRL. Out of five insecticides tested in poly house phosalone, flubendiamide and profenophos residues are found in capsicumes up to 10 days, while dimethoate and lambda-cyhalothrin are detected up to 7 days. Whereas in open field phosalone and profenophos residues are found up to week while dimethoate, lambda-cyhalothrin and flubendiamide are detected up to five days.
\end{abstract}

\section{INTRODUCTION}

Capsicum (Capsicum annum L.), also called "Bell pepper," is an important commerical crop in India and suffers major quantitative and qualitative loss in production due to capsicum thrips, Scirtothrips dorsalis Hood and yellow mite, Polyphagotarsonemus latus (Banks) and fruit borers Helicoverpa armigera (Hubner). A number of pesticides are being frequently used, to combat these pests. However, some of these insecticides leave residues on fruits and these residues may persist up to harvest. Presence of pesticide residues in the harvested capsicum is posing problem at the time of export and in recent times importing countries have rejected few consignments. Pesticide use has increased rapidly over the last two decades at the rate of $12 \%$ per year (Thacker et al., 2005[1]). Many farm gate capsicum samples showed presence of insecticide residues (Singh et al., 1999)[2].As per insecticides Act of 1968 (www.cibrc.nic.in)[3], 37 insecticide formulations are registered and recommended for use on capsicum targeting various pests. In recent years due to the support of the Government under National Horticulture Mission (NHM), capsicum is widely cultivated under poly house conditions. Since the persistence and dissipation of insecticides in poly houses will be different from normal conditions, the present study is proposed to monitor the pesticide usage on capsicum, dissipation studies of recommended pesticides both in poly house and open field conditions, so as to recommend the safe waiting periods based on the Maximum Residue Limits (MRLs) calculated, as it helps in recommending risk mitigation protocols for food safety. 


\section{MATERIALS AND MeThODS}

Certified Reference Materials (CRMs) of Dimethoate, $\lambda$-cyhalothrin, Phosalone, Flubendiamide and Profenophos from Dr. Erhenstorfer, Germany were utilized for preparing working standards which were injected into Gas Chromatograph with Electron Capture Detector (ECD) and Thermionic Specific Detector (TSD) for estimating the lowest quantity of these pesticides which can be detected with injector splitters ratio of 1:10 under standard operating parameters

For confirmatory analysis, dimethoate, $\lambda$-cyhalothrin, phosalone and profenophos were analysed on both ECD and TSD as these pesticides can be detected on both detectors simultaneously using "Universal Y splitters" at the detector end. One micro litre of each working standard was injected for the study. The retention times of dimethoate, $\lambda$-cyhalothrin, phosalone and profenophos were 9.95 , 11.87, 6.99 and $5.27 \mathrm{~min}$, respectively. Each working standards of above mentioned pesticides $(0.01$ ppm, $0.025 \mathrm{ppm}, 0.05 \mathrm{ppm}, 0.075 \mathrm{ppm}, 0.10 \mathrm{ppm}, 0.25 \mathrm{ppm}$ and $0.50 \mathrm{ppm})$ were injected 6 times and the linearity lines were drawn. Based on the response of the detector (ECD) to different quantities (ng) of CRM standards injected, the LOD (limit of detection) for dimethoate is $0.01 \mathrm{ng}$, and the linearity is in the range of $0.01 \mathrm{ng}$ to $0.10 \mathrm{ng}$ For lamda cyhalothrin is $0.01 \mathrm{ng}$, and the linearity is in the range of $0.01 \mathrm{ng}$ to $0.10 \mathrm{ng}$, the LOD (limit of detection) for phosalone is $0.01 \mathrm{ng}$, and the linearity is in the range of $0.01 \mathrm{ng}$ to $0.10 \mathrm{ng}$, whereas for profenophos it is $0.01 \mathrm{ng}$, and the linearity is in the range of $0.01 \mathrm{ng}$ to $0.10 \mathrm{ng}$

The working standards of flubendiamide were injected to Liquid Chromatograph with Photo Diode Array (PDA) Detector for estimating the lowest quantity of flubendiamide under standard operating parameters Table. For confirmatory analysis samples were also injected in LC-MS/MS., the retention time of flubendiamide was $4.25 \mathrm{~min}$. Working standards of flubendiamide $(0.05 \mathrm{ppm}, 0.075 \mathrm{ppm}$, $0.10 \mathrm{ppm}, 0.25 \mathrm{ppm}$ and $0.50 \mathrm{ppm}$ ) were injected 6 times and the linearity lines were drawn the LOD (limit of detection) for flubendiamide is $0.05 \mathrm{ng}$, and the linearity is in the range of $0.05 \mathrm{ng}$ to $0.10 \mathrm{ng}$

\subsection{Method Valilidation and Fortification Recoveries}

Prior to pesticide application and field sample analysis, the residue analysis method was validated following the SANCO document (12495/2011). The capsicum fruits $(5 \mathrm{~kg})$ collected from untreated control plots were brought to the laboratory, homogenized using Robot Coupe Blixer (High volume homogenizer) and $15 \mathrm{~g}$ sample was taken in to $50 \mathrm{ml}$ centrifuge tubes. The required quantity of Dimethoate, $\lambda$-cyhalothrin, Phosalone, Flubendiamide and Profenophos intermediary standard prepared from CRMs were added to each sample to get fortification levels of $0.05 \mathrm{ppm}, 0.25 \mathrm{ppm}$ and $0.5 \mathrm{ppm}$, in three replications each. These foritifcation levels are selected to know the suitability of the method to detect and quantify pesticides in capsicum below Maximum Residue Limits (MRLs) of Codex Alimentarius Commission (CAC).

The AOAC official method 2007.01 (Pesticide Residues of Foods by Acetonitrile Extraction and Partitioning with Magnesium Sulfate) was slightly modified to suit to the facilties available at the laboratory and the same was validated for estimation of LOQ (Limit of Quantification) of above mentioned pesticides in Capsicum matrix. The Quechers method was followed as presented in the flow chart The final extract of the sample i.e. $2 \mathrm{ml}$ equal to $1 \mathrm{~g}$ of the sample was evaporated using turbovap and made up to $1 \mathrm{ml}$ (equal to $1 \mathrm{~g}$ sample) using suitable solvent for analysis on GC, while for LC analysis, filtered $1 \mathrm{ml}$ final extract (equal to $0.5 \mathrm{~g}$ sample) was directly injected in LC and the residues of pesticides recovered from fortified samples were calculated using the following formula.

Sample weight (15 g) X aliquot taken

Wt of the Sample analysed $=\frac{\text { Volume of acetonitrile }(30 \mathrm{ml})}{2}$

\section{RESULTS AND DISCUSSION}

For the analysis of dimethoate residues up to $0.05 \mathrm{mg} \mathrm{kg}^{-1}$, and the limit of quantification (LOQ) is $0.05 \mathrm{mg} \mathrm{kg}^{-1}$. Capsicum samples fortified with phosalone $0.25 \mathrm{mg} \mathrm{kg}^{-1}$ and $0.5 \mathrm{mg} \mathrm{kg}^{-1}$ were analysed and the mean recovery of the residues using the method was $90.86 \%$ and $98.61 \%$, respectively and the results show that the method is suitable for the analysis of lamda cyhalothrin residues up to $0.25 \mathbf{~ m g ~ k g}^{-1}$, and the limit of quantification (LOQ) is $0.25 \mathbf{~ m g ~ k g}^{-1}$. Capsicum samples fortified with profenophos at $0.05 \mathrm{mg} \mathrm{kg}^{-1}, 0.25 \mathrm{mg} \mathrm{kg}^{-1}$ and $0.5 \mathrm{mg} \mathrm{kg}^{-1}$ were analysed and the mean recovery of the residues using the method was $92.41 \%, 98.45 \%$ and $95.34 \%$, respectively and the results show 
that the method is suitable for the analysis of profenophos residues up to $0.05 \mathbf{~ m g ~ k g}^{-1}$, and the limit of quantification (LOQ) is $0.05 \mathbf{~ m g ~ k g}$. Capsicum samples fortified with flubendiamide at $0.05 \mathrm{mg} \mathrm{kg}^{-1}, 0.25 \mathrm{mg} \mathrm{kg}^{-1}$ and $0.5 \mathrm{mg} \mathrm{kg}^{-1}$ were analysed and the mean recovery of the residues using the method was $90.69 \%, 94.76 \%$ and $104.34 \%$, respectively, and the results show that the method is suitable for the analysis of flubendiamide residues up to $0.05 \mathbf{~ m g ~ k g}^{-1}$, and the limit of quantification (LOQ) is $\mathbf{0 . 0 5 ~} \mathrm{mg} \mathrm{kg}^{-1}$.

\subsection{Dissipation of Dimethoate}

The initial deposit and subsequent residues of dimethoate on capsicum in open field and poly house situation at an interval of $0,1,3,5,7,10,15$ and 20 days after second spray are presented in Table 2.In open field situation, the initial deposit of $0.19 \mathrm{mg} \mathrm{kg}-1$ gradually dissipated to $0.14,0.10$ and 0.08 $\mathrm{mg} \mathrm{kg-1}$ at 1,3 and 5 days, respectively. The per cent dissipation was 26.31, 47.36 and 57.89, respectively. The residues fell Below Determination Level (BDL) of $0.05 \mathrm{mg} \mathrm{kg}-1$ by $7^{\text {th }}$ day. The half-life (RL50) of dimethoate was worked to be 36.47 days. The regression equation was $\mathrm{Y}=0.171$ $+(-0.019) \mathrm{X}$ with $\mathrm{R}^{2}$ of 0.902 . There are no maximum residue limits (MRL) for dimethoate on chilli as per Codex Alimentarius Commission (CAC), while Food Safety and Standards Authority of India (FSSAI) \{4]suggests $2 \mathrm{mg} \mathrm{kg}^{-1}$ for fruits and vegetables, and hence safe waiting period of 1 day can be suggested, as the initial deposits are less than the MRL. The half life of dimethoate on capsicum was 36.47 days in open field situation .In poly house, initial deposits of $2.42 \mathrm{mg} \mathrm{kg}^{-1}$ were detected, which dissipated to $0.10 \mathrm{mg} \mathrm{kg}^{-1}$ by 7 th day after the second spray. The residues of $0.86,0.39,0.34$ and 0.10 $\mathrm{mg} \mathrm{kg}^{-1}$ were recorded at $1,3,5$ and 7 days, respectively and dissipated to $64.46,83.88,85.95$ and 95.86 per cent on $1,3,5$ and $7^{\text {th }}$ day, respectively. The results showed that the residues of dimethoate reached Below Determination Level (BDL) of $0.05 \mathrm{mg} \mathrm{kg}-1$ in 10 days while half-life was worked out to be 2.61 days. The regression equation was $\mathrm{Y}=1.671+(-0.265) \mathrm{X}$ with $\mathrm{R}^{2}$ of 0.664 .There are no maximum residue limit for dimethoate in capsicum as per Codex Alimentarius Commission (CAC) while Food Safety and Standards Authority of India (FSSAI) suggests $2 \mathrm{mg} \mathrm{kg}^{-1}$ for vegetables,and hence based on the present study, PHI of 7 days can be recommended as the residues degraded to BDL by $10^{\text {th }}$ day.

it is evident that there is clear difference in dissipation pattern of dimethoate in poly house and open fields. Initial deposit of $2.42 \mathrm{mg} \mathrm{kg}^{-1}$ was recorded in poly house, where as in open fields it was 0.19 $\mathrm{mg} \mathrm{kg}^{-1}$. Dimethoate reached Below Determination Level (BDL) of $0.05 \mathrm{mg} \mathrm{kg}^{-1}$ by $10^{\text {th }}$ day in poly house, whereas in open field trial by $7^{\text {th }}$ day. Capsicum samples fortified with lamda cyhalothrin at $0.05 \mathrm{mg} \mathrm{kg}^{-1}, 0.25 \mathrm{mg} \mathrm{kg}^{-1}$ and $0.5 \mathrm{mg} \mathrm{kg}^{-1}$ were analysed and the mean recovery of the residues using the method was $91.69 \%, 95.88 \%$ and $109.16 \%$, respectively and the results show that the method is

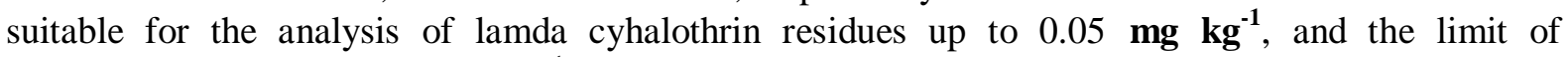
quantification (LOQ) is $0.05 \mathrm{mg} \mathrm{kg}^{-1}$.

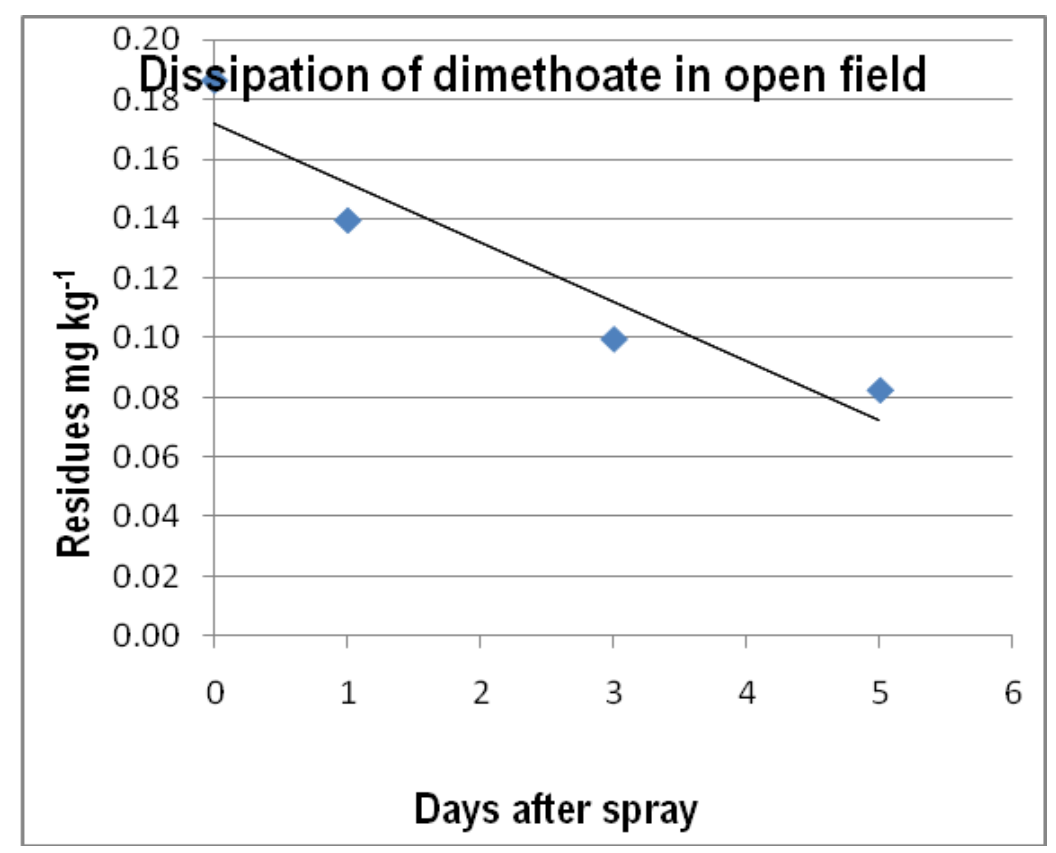




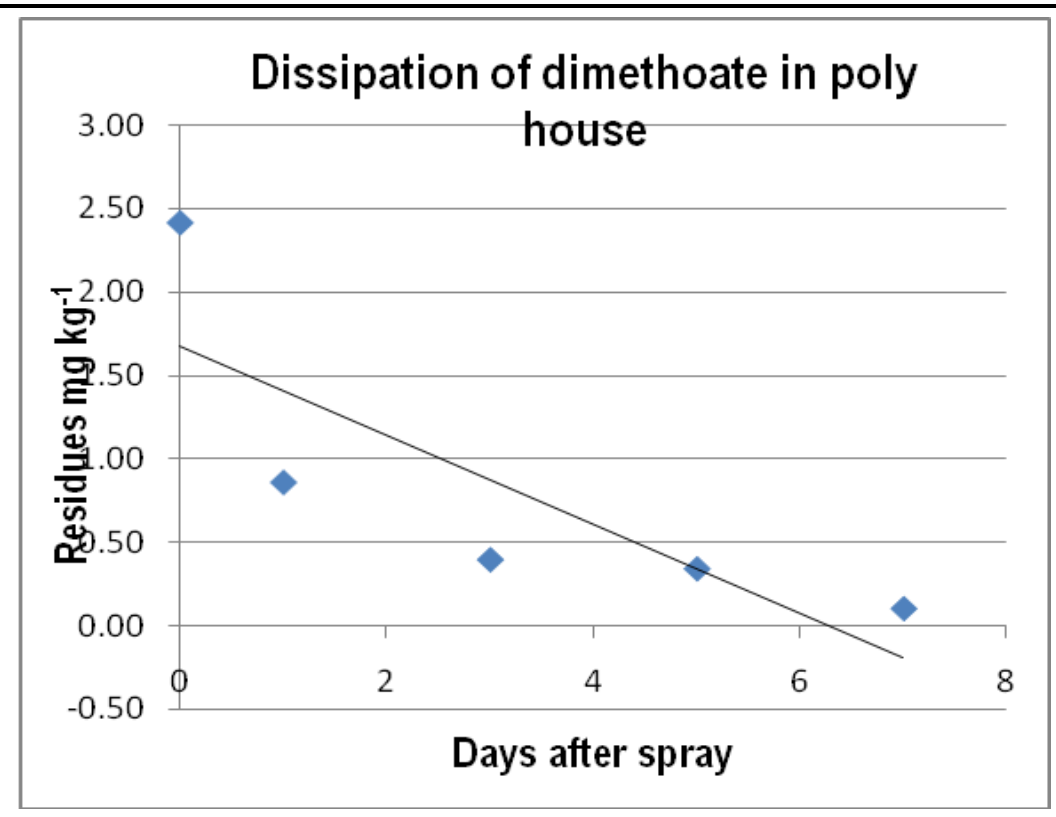

\subsection{Dissipation of Lambda Cyhalothrin}

The dissipation pattern of Lambda cyhalothrin on capsicum in open field and poly house situation at an interval of $0,1,3,5,7,10,15$ and 20 days after second spray are presented in Table 4 The initial deposit of $0.16 \mathrm{mg} \mathrm{kg}-1$ on capsicum in open field situations dissipated to $0.12,0.07$ and $0.06 \mathrm{mg} \mathrm{kg}$ 1 at 1, 3 and 5 days with per cent dissipation of 25,56.25 and 62.5, respectively. The half-life (RL50) of Lambda cyhalothrin in capsicum fruits was worked out to be 34.65 days. The residues of Lambda cyhalothrin dissipated to Below Determination limit of $0.05 \mathrm{mg} \mathrm{kg}-1$ in 7 days.

There are no MRLs suggested for lambda cyhalothrin in capsicum by either Codex Alimentarius Commission (CAC) or by Food Safety and Standards Authority of India (FSSAI), but as per Insecticide Act, 1968, while recommending lambda cyhalothrin @ $15 \mathrm{~g}$ a.i. ha ${ }^{-1}$ for fruit borer management, PHI of 5 days was recommended. Since no MRLs are available, PHI of 5 days can be recommend as the residues dissipated to $0.06 \mathrm{mg} \mathrm{kg}$-1.In poly house, Initial deposits of $0.37 \mathrm{mg} \mathrm{kg}^{-1}$ lambda cyhalothrin detected at 2 hours after last spray, dissipated to Below Determination Level (BDL) of $0.05 \mathrm{mg} \mathrm{kg}-1$ by $10^{\text {th }}$ day after last spraying on capsicum and the initial deposits dissipated to $0.12,0.11,0.07$ and $0.05 \mathrm{mg} \mathrm{kg}-1$ by $1,3,5$ and 7 days after last spray, respectively. The dissipation pattern showed decrease of residues from first day to 7 th day and residues dissipated by $67.56,70.27,81.08$ and $86.48 \%$ at $1,3,5$ and 7 days, respectively. The regression equation was $\mathrm{Y}=$ $0.256+(-0.035) \mathrm{X}$ with R2 of 0.607 . There are no MRLs suggested for lambda cyhalothrin in capsicum by either Codex Alimentarius Commission (CAC) or by Food Safety and Standards Authority of India (FSSAI), but as per Insecticide Act, 1968, while recommending lambda cyhalothrin@15 g a.i. ha ${ }^{-1}$ for fruit borer management, PHI of 7 days was recommended for poly house sprays. Since no MRLs are available, PHI of 7 days can be recommend as the residues dissipated to $0.05 \mathrm{mg} \mathrm{kg}^{-1}$.

Since sufficient literature is not available on the dissipation pattern of lambda cyhalothrin in capsicum or on related crops in poly houses information available on related crops is also taken into account for discussion of open field data only. The above findings are in agreement with results of Jayakrishna et al. (2005) [5]who reported that lambda cyhalothrin sprayed @ $15 \mathrm{~g}$ a.i. ha ${ }^{-1}$ on tomato fruits recorded initial deposit of $0.38 \mathrm{mg} \mathrm{kg}^{-1}$ and residues reached Below Determination Level (BDL) by $7^{\text {th }}$ day, they suggested waiting period of 3 days. At double the recommended dose i.e. @ $30 \mathrm{~g}$ a.i. ha ${ }^{-1}$, initial deposit of $0.52 \mathrm{mg} \mathrm{kg}^{-1}$ dissipated to BDL by $10^{\text {th }}$ day, with half-life of 3.7 days. The findings of present investigations are also in line with results of Natekar et al. (1988) [6]who found that lambda cyhalothrin sprayed @ $0.005 \%$ on brinjal recorded initial deposit of $0.13 \mathrm{mg} \mathrm{kg}^{-1}$ and residues reached Below Determination Level (BDL) by $8^{\text {th }}$ day and suggested waiting period of 1 day.The dissipation dynamics of lambda cyhalothrin on capsicum in both open filed and poly house are in first order kinetics, and are in agreement with the results of Ahuja et al. (2006)[7] on brinjal at both recommended (@15 g a.i. ha $\mathrm{a}^{-1}$ ) and double dosage (@30 g a.i. ha ${ }^{-1}$ ) where the initial deposits of 0.75 $\mathrm{mg} \mathrm{kg}{ }^{-1}$, and $1.27 \mathrm{mg} \mathrm{kg}^{-1}$ dissipated to BDL in 10 days, respectively. Reddy et al. (2007)[8] using lambda cyhalothrin on capsicum at $50 \mathrm{~g}$ a.i. ha-1,recordedinitial deposits of $0.62 \mathrm{mg} \mathrm{kg}-1$. 

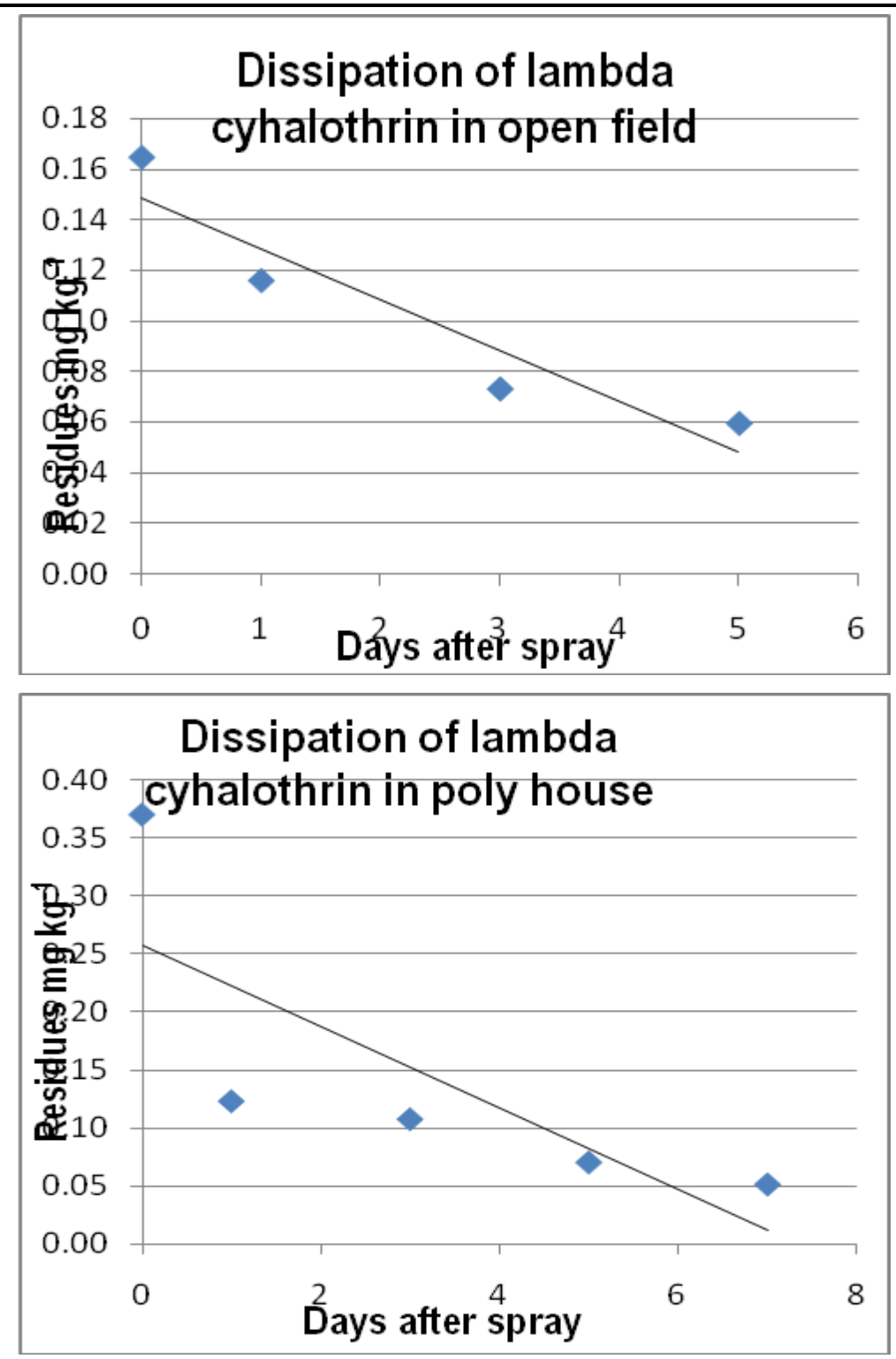

\subsection{Dissipation of Phosalone}

In open field studies, initial deposits of $4.21 \mathrm{mg} \mathrm{kg}^{-1}$ of phosalone was detected at 2 hours after last spray, which dissipated to Below Detectable Level (BDL) of $0.25 \mathrm{mg} \mathrm{kg}^{-1}$ by $10^{\text {th }}$ day after last spray. The initial deposits dissipated to $2.44,1.15,0.81$ and $0.48 \mathrm{mg} \mathrm{kg}^{-1}$ by $1,3,5$ and 7 days after last spray, respectively. The residues dissipated by $42.04,72.68,80.76$ and $88.59 \%$ at $1,3,5$ and 7 days, respectively. Phosalone is recommended for use on capsicum against fruit borer as per Insecticide Act, $1968 @ 450 \mathrm{~g}$ a.i. ha $^{-1}$ and Food Safety and Standards Authority of India (FSSAI) fixed MRL as $1 \mathrm{mg} \mathrm{kg}^{-1}$ for vegetables. As per the Act, PHIs are not recommended as Codex, MRLs are not fixed for phosalone on capsicum. Based on the results, it is found that the half-life of phosalone on capsicum is 1.44 days in open field, and hence a safe waiting period (PHI) of 7 days can be recommended as the residues dissipated to LOQ of $0.25 \mathrm{mg} \mathrm{kg}^{-1}$ by $7^{\text {th }}$ day. In poly house an initial deposit of $5.35 \mathrm{mg} \mathrm{kg}^{-1}$ at 2 hours after last spray dissipated to $2.92,1.96,1.39,0.81$ and $0.50 \mathrm{mg} \mathrm{kg}^{-1}$ by $1,3,5$, 7and 10 days, respectively, and BDL of $0.25 \mathrm{mg} \mathrm{kg}^{-1}$ by $15^{\text {th }}$ day. The residues dissipated by $45.42,63.36,74.01,84.8$ and $90.6 \%$ at $1,3,5,7$ and 10 days, respectively. There are no maximum residue limit for phosalone in capsicum as per Codex Alimentarius Commission (CAC) while Food Safety and Standards Authority of India (FSSAI) suggests $1 \mathrm{mg} \mathrm{kg}^{-1}$ for vegetables and hence based on the present study, PHI of 10 days can be recommended as the residues degraded to BDL by $15^{\text {th }}$ day. From Tables, it is evident that there is a clear difference in dissipation pattern of phosalone in poly house and open fields. Initial deposit of $5.35 \mathrm{mg} \mathrm{kg}^{-1}$ was recorded in poly house, where as in open fields it was $4.21 \mathrm{mg} \mathrm{kg}^{-1}$, which dissipated to BDL of $0.25 \mathrm{mg} \mathrm{kg}^{-1}$ by $10^{\text {th }}$ day and $15^{\text {th }}$ day, respectively. Half-life value of 1.44 days were recorded in poly house and 1.66 days in open field field conditions 
In general, the studies conducted by various scientists (Rajukannu et al, 1979) [9] on dissipation of phosalone on tomato suggested that an initial deposit of 7.40-7.80 mg kg ${ }^{-1}$ dissipated to BDL by 7-10 days depending up on the stage of application at a dose of $700 \mathrm{~g}$ a.i. ha ${ }^{-1}$, and in the present study, an initial deposit of $4.21 \mathrm{mg} \mathrm{kg}^{-1}$ in open field, and $5.35 \mathrm{mg} \mathrm{kg}^{-1}$ in poly house from $450 \mathrm{~g}$ a.i. ha ${ }^{-1}$ applied plots suggests that the results are in full agreement with the general trend. The findings of present investigation are in agreement with results of Pareek et al. (1990)[10] who reported that initial deposits of phosalone $4.74 \mathrm{mg} \mathrm{kg}^{-1}$ dissipated and persisted up to $7^{\text {th }}$ day with half-life values of 2.96 days when applied @ $310 \mathrm{~g}$ a.i. $\mathrm{ha}^{-1}$ on round gourd. Rajukannu et al. (1980)[11] reported that phosalone ,applied @ $700 \mathrm{~g}$ a.i. ha ${ }^{-1}$ on brinjal reached Below Determination Level (BDL) by $5^{\text {th }}$ day with half-life value of 1.56 and suggested waiting period of 1.55 days. Based on the available literature on dissipation of phosalone on various vegetable crops, it is clear that in most cases, the initial deposits are in the range of 7 to $10 \mathrm{mg} \mathrm{kg}^{-1}$ at recommended doses which dissipated to BDL in 7-15 days, depending up on the season and crop. In the present study on capsicum, phosalone dissipation pattern is in agreement with all available literature clearly indicating that phosalone dissipates to BDL in 10-15 days depending up on the crop management practices. In the existing circumstances where no MRLs are available, PHI of 7 days for poly house and 1o days for open field situations can be safety suggested for food safety.

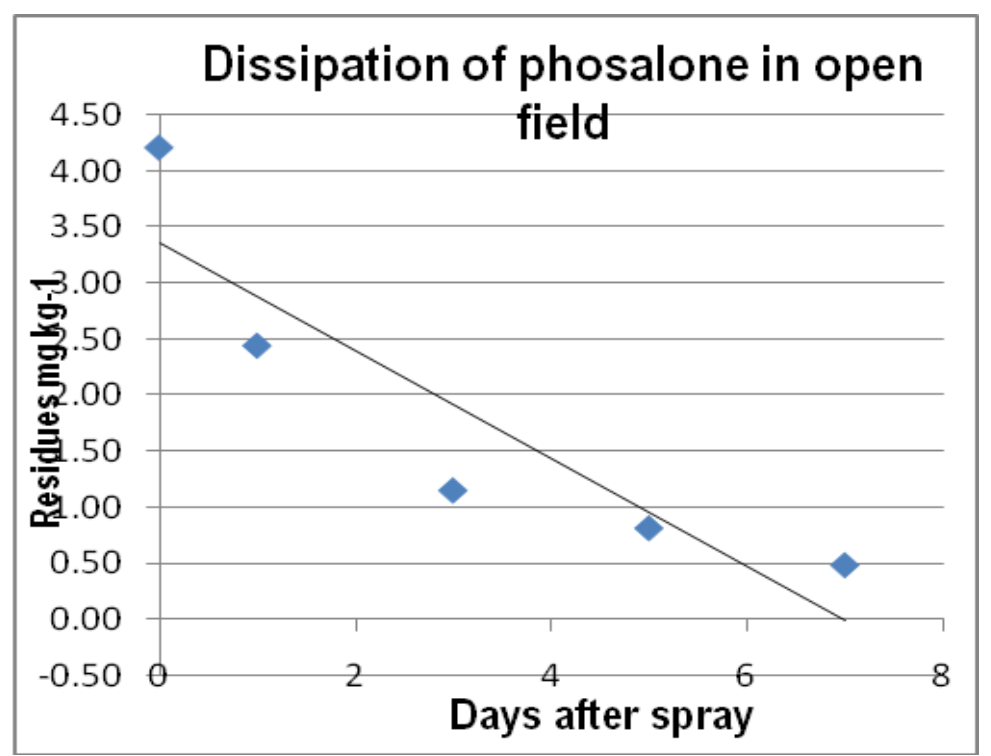

\subsection{Dissipation of Flubendiamide}

The dissipation dynamics of flubendiamide was studied in open field and poly house situations collecting samples at $0,1,3,5,7,10,15$ and 20 days after second spray In open field situation, initial deposits of $0.76 \mathrm{mg} \mathrm{kg}^{-1}$ offlubendiamide detected at 2 hours after last spray, dissipated to $0.50,0.27$ and $0.15 \mathrm{mg} \mathrm{kg}^{-1}$ and Below Determination Level (BDL) of $0.05 \mathrm{mg} \mathrm{kg}^{-1}$ by 1,3 and 5 days after last spray, respectively and dissipated by $34.21,66.47$ and $80.26 \%$ at 1,3 , and 5 days, respectively. The regression equation was $\mathrm{Y}=0.682+(-0.115) \mathrm{X}$ with $\mathrm{R}^{2}$ of 0.918. Maximum Residue Limits (MRLs) are not fixed for flubendiamide on capsicum as per FSSAI, while Codex Alimentarius Commission (CAC)has set as $2 \mathrm{mg} \mathrm{kg}^{-1}$. Based on the present study, safe waiting period of 1 day can be suggested as the initial deposits are less than the MRL. The half-life of flubendiamide on capsicum was 6.02 days.Initial deposits of $1.19 \mathrm{mg} \mathrm{kg}^{-1}$ flubendiamide were detected at 2 hours after last spray, which dissipated to Below Determination Level (BDL) of $0.05 \mathrm{mg} \mathrm{kg}^{-1}$ by $7^{\text {th }}$ day in poly house conditions. The initial deposits dissipated to $0.89,0.64,0.39$ and $0.17 \mathrm{mg} \mathrm{kg}^{-1}$ in $1,3,5,7$ and 10 days after last spray, respectively. The residues dissipated by $25.21,46.21,66.22,85.71$ and $88.23 \%$ at $1,3,5,7$ and 10 days, respectively. The regression equation was $\mathrm{Y}=1.022+(-0.104) \mathrm{X}$ with $\mathrm{R}^{2}$ of 0.899.Maximum Residue Limits (MRLs) are not fixed for flubendiamide on capsicum as per FSSAI, while Codex Alimentarius Commission (CAC) set as $2 \mathrm{mg} \mathrm{kg}^{-1}$. Based on the present study, safe waiting period of 1 day can be suggested as the initial deposits are less than the MRL. The half-life of flubendiamide on capsicum was 6.66 days.It is evident that there is a clear difference in dissipation pattern of flubendiamide in poly house and open fields. Initial deposit of $1.19 \mathrm{mg} \mathrm{kg}^{-1}$ was recorded in poly house, where as in open fields it was $0.76 \mathrm{mg} \mathrm{kg}^{-1}$, reaching Below Determination Level (BDL) of $0.05 \mathrm{mg} \mathrm{kg}^{-1}$ by $15^{\text {th }}$ day and $7^{\text {th }}$ day, respectively.As per CIBRC and Insecticide Act, 1968, 
flubendiamide is recommended for use on capsicum @ $48 \mathrm{~g}$ a.i. ha ${ }^{-1}$ for controlling fruit borer. The same dosage was used in the present study to know the dissipation dynamics in two situations and it is evident that $0.76 \mathrm{mg} \mathrm{kg}^{-1}$ initial deposits dissipated to BDL level by $7^{\text {th }}$ day in open field situation, and the findings of present investigation are in agreement with the results of Sahoo et al. (2009)[12] who reported that flubendiamide sprayed on capsicum @ $60 \mathrm{~g}$ a.i. ha ${ }^{-1}$ resulted in initial deposit of $1.06 \mathrm{mg}$ $\mathrm{kg}^{-1}$ and dissipated to BDL in 7 days and at higher dose, it took 10 days. Sharma and Parihar (2013)[13] who reported that flubendiamide persisted up to 5 days after application on tomato @ $48 \mathrm{~g}$ a.i. ha ${ }^{1}$. Similar results were reported by Kooner et al. (2010) [14]who reported that flubendiamide persisted up to 5 days after application on tomato @ $48 \mathrm{~g}$ a.i. $\mathrm{ha}^{-1}$. The flubendiamide in poly house (controlled environment) dissipated at very slow rate and degraded to BDL by $15^{\text {th }}$ day. Similar trends were also reported by many workers on other vegetables as well. Jyothsna et al. (2012)[15] reported that flubendiamide sprayed on gherkin @ $48 \mathrm{~g}$ a.i. ha ${ }^{-1}$ gave initial deposit of $0.92 \mathrm{mg} \mathrm{kg}^{-1}$ and residues reached Below Determination Level (BDL) by $10^{\text {th }}$ day.The research findings of Paramasivam and Banerjee (2013)[16], showed that flubendiamide spray on cabbage @ $25 \mathrm{~g}$ a.i. ha ${ }^{-1}$ resulted in $0.31 \mathrm{mg}$ $\mathrm{kg}^{-1}$ deposits but persisted up to 15 days to reach BDL, indicating very slow dissipation rates on cabbage. Similar results were reported by Mohapatra et al. (2010) [17]where flubendiamide spray on cabbage @ $48 \mathrm{~g}$ a.i. ha ${ }^{-1}$ resulted in $0.49 \mathrm{mg} \mathrm{kg}^{-1}$ deposit and took 15 days for dissipation to BDL.Based on the literature it is very clear that flubendiamide dissipates at very slow rate, but however, as the Codex MRL is $2 \mathrm{mg} \mathrm{kg}^{-1}$ on capsicum, it can be safely recommended for use with 1 day PHI as initial deposits are below MRL in both cases. Since the Indian government recommends flubendiamide on capsicum, MRL of $2 \mathrm{mg} \mathrm{kg}^{-1}$ can also be taken as provisional MRL as per FSSAI, since the initial deposits are very low due to low dose recommendation.
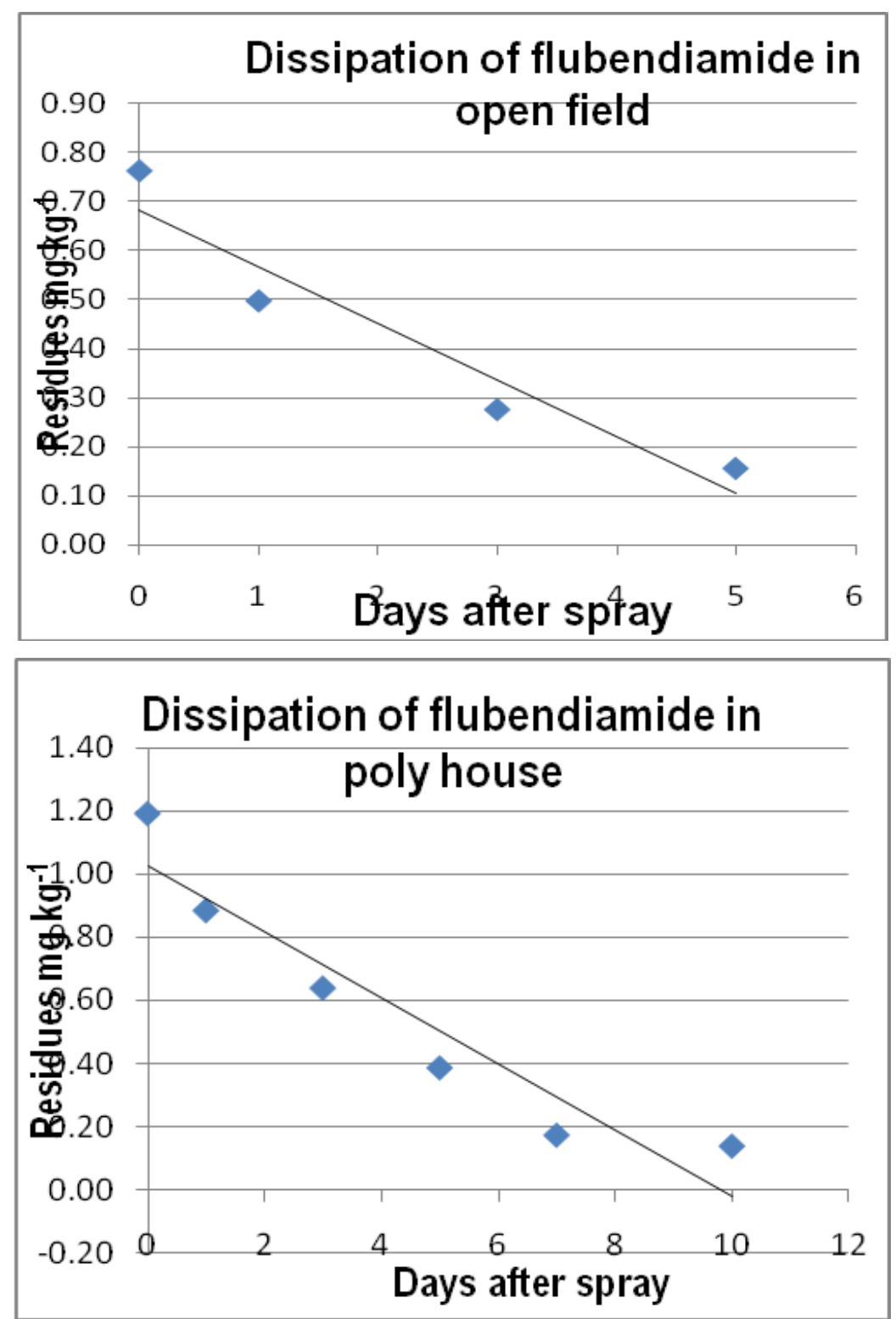


\subsection{Dissipation of Profenophos}

The residue data of profenophos from the studies conducted in open field and poly house situation. Profenophos is not registered for use on capsicum as per Insecticide Act, 1968, but based on the survey reports, it is very much evident that profenophos is most popular and commonly used pesticide and hence, field trial was conducted based on the farmer's practice dose @ $500 \mathrm{~g} \mathrm{a.i} \mathrm{ha}^{-1}$ to study the dissipation pattern. The study revealed that the initial deposits of $2.24 \mathrm{mg} \mathrm{kg}^{-1}$ (at 2 hours after last spray) dissipated to Below Determination Level (BDL) of $0.05 \mathrm{mg} \mathrm{kg}^{-1}$ by $10^{\text {th }}$ day after last spraying on capsicum. The initial deposits dissipated to $1.26,0.76,0.47$ and $0.18 \mathrm{mg} \mathrm{kg}^{-1}$ by $1,3,5$ and 7 days after last spray, respectively. The residues dissipated by $43.75,66.07,79.01$ and $91.96 \%$ at $1,3,5$ and 7 days, respectively. The regression equation was $\mathrm{Y}=1.821+(-0.262) \mathrm{X}$ with $\mathrm{R}^{2}$ of 0.858 . As the Indian Government does not recommend profenophos on capsicum, MRLs are also not set. However, maximum residue limit for profenophos in capsicum are set by Codex Alimentarius Commission (CAC) and European Union (EU) as $10 \mathrm{mg} \mathrm{kg}^{-1}$. Based on the present investigations, it can be concluded and recommended that a PHI of 1 day is good for food safety when profenophos is applied. In poly house experiment, initial deposits of $3.71 \mathrm{mg} \mathrm{kg}^{-1}$ of profenophos were detected at 2 hours after last spray, which dissipated to Below Determination Level (BDL) of $0.05 \mathrm{mg} \mathrm{kg}^{-1}$ by $15^{\text {th }}$ day after last spraying on capsicum, indicating that profenophos dissipation is slow in poly house compared to open fields. The initial deposits dissipated to $2.24,1.27,0.66,0.33$ and $0.17 \mathrm{mg} \mathrm{kg}^{-1}$ by $1,3,5,7$ and 10 days after last spray, respectively. The residues dissipated by $39.62,65.76,82.21$, 91.10 and $95.41 \%$ at $1,3,5,7$ and $10^{\text {th }}$ days, respectively. The regression equation was $\mathrm{Y}=2.788+(-$ 0.321) $\mathrm{X}$ with $\mathrm{R}^{2}$ of 0.797 .As the Indian Government does not recommend profenophos on capsicum, MRLs are also not set. However, maximum residue limit for profenophos in capsicum are set by Codex Alimentarius Commission (CAC) and European Union (EU) as $10 \mathrm{mg} \mathrm{kg}^{-1}$. Based on the present investigation, it can be concluded and recommended that a PHI of 1 day is good for food safety when profenophos applied on capsicum in poly house. From table 2 it is evident that there is a clear difference in dissipation pattern of profenophos in poly house and open fields. Initial deposit of $3.71 \mathrm{mg} \mathrm{kg}^{-1}$ was recorded in poly house, where as in open fields it was $2.24 \mathrm{mg} \mathrm{kg}^{-1}$. Profenophos reached Below Determination Level (BDL) of $0.05 \mathrm{mg} \mathrm{kg}^{-1}$ by $15^{\text {th }}$ day in poly house whereas, in open field trial by $10^{\text {th }}$ day. The results are in full agreement with the findings of Ahmad et al.(2009)[18] who reported that profenophos spray on tomato @ $500 \mathrm{~g} \mathrm{a.i.}^{-1} \mathrm{~h}^{-1}$, resulted in initial deposit of $2.58 \mathrm{mg} \mathrm{kg}^{-1}$ dissipating to BDL in 15 days and similar results were also reported by Sahoo et al. (2004) on tomato. Various workers suggested safe waiting periods varying from 1 to 14 days, but as per CCPR guidelines based on CAC MRLs $\left(10 \mathrm{mg} \mathrm{kg}^{-1}\right)$ it is not necessary to recommend waiting periods till the residues reach BDL, and taking into consideration of MRLs set by CAC and results on dissipation dynamics on capsicum in present study, it can be scientifically concluded and recommended that PHI of 1 day is exceedingly good as the initial deposits are well below $10 \mathrm{mg} \mathrm{kg}$ -

${ }^{1}$.Experimental results of Radwan et al. (2004[19]) show that at application of very high dose @ 1280 g a.i. ha ${ }^{-1}$ on three crops viz., green pepper, hot pepper and brinjal resulted in very high initial deposit of $10-11 \mathrm{mg} \mathrm{kg}^{-1}$ on pepper and $4.50 \mathrm{mg} \mathrm{kg}^{-1}$ on brinjal, which dissipated to BDL in 2 weeks. However, the studies conducted by various workers (Gupta et al 20110[20]., Renuka et al 2006[21]., Katroju et al., 2014)[22] on dissipation on profenophos on different crops clearly indicates that when applied at recommended dose, the initial deposits are less than $3 \mathrm{mg} \mathrm{kg}^{-1}$ and dissipate to BDL in 7-10 days depending on the crop, except on cardamom. Based on dissipation studies on dimethoate in both open field and poly house, it is concluded that residues dissipated to BDL in 7 and 10 days, respectively and taking into consideration of initial deposits and MRLs suggested by FSSAI, PHI of 1 day and 7 day are recommended in open field and poly house respectively. Lambda cyhalothrin applied @ $15 \mathrm{~g}$ a.i. $\mathrm{ha}^{-1}$ recorded initial deposits of $0.37 \mathrm{mg} \mathrm{kg-}^{1}$ which dissipated to BDL in 10 days in poly house, while in open field trial, residues dissipated to BDL in 7 days. There are no MRLs suggested by either (CAC) or by (FSSAI), Taking BDL in to consideration PHI of 5 day and 7 day are recommended in open field and poly house respectively. Phosalone applied in both open field and poly house, dissipated at faster rate taking into consideration of high initial deposits, but taking into consideration MRL of FSSAI i.e $1 \mathrm{mg} \mathrm{kg}^{-1}$, PHI of 7 day and 15 days are recommended in open field and poly house, respectively. Based on dissipation studies on flubendiamide in both open field and poly house, it is concluded that residues dissipated to BDL in 7 and 15 days, respectively. Taking 
BDL into consideration PHI of 5 day and 10 day are recommended in open field and poly house respectively. Profenophos applied in both open field and poly house, it is concluded that residues dissipated to BDL in 10 and 15 days, respectively and taking into consideration of initial deposits and MRLs suggested by FSSAI, one day PHI can be recommended.
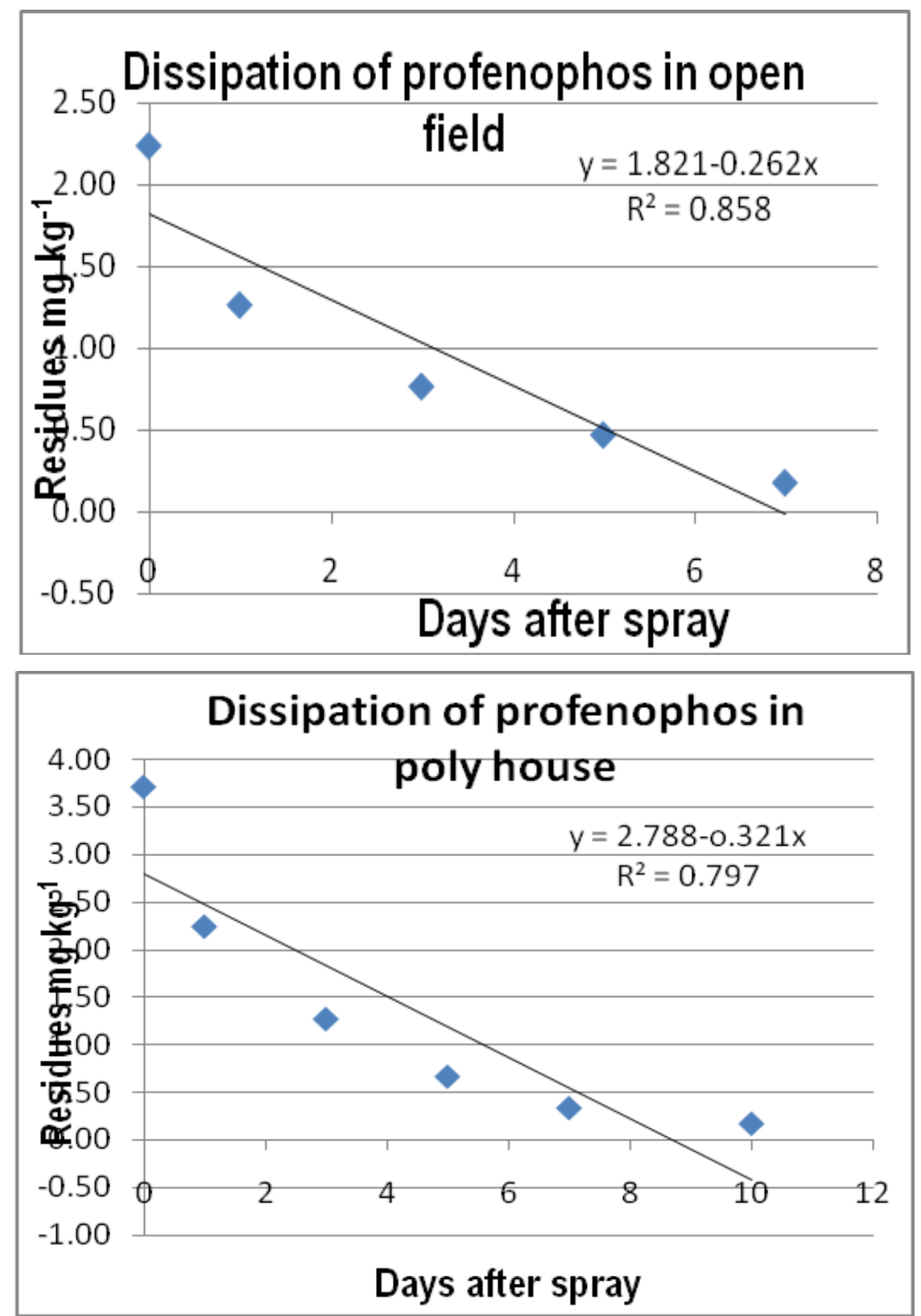

Table1. Dissipation of different insecticides in Capsicum in open fields

\begin{tabular}{|c|c|c|c|c|c|c|c|c|c|c|}
\hline \multirow{2}{*}{$\begin{array}{c}\text { Days after last } \\
\text { spray } \\
\end{array}$} & \multicolumn{5}{|c|}{ Residues of different insecticides $\left(\mathrm{mg} \mathrm{kg}^{-1}\right)$} & \multicolumn{5}{|c|}{ Dissipation\% } \\
\hline & $\begin{array}{c}\text { Dimetho } \\
\text { ate }\end{array}$ & $\begin{array}{l}\text { Lambda } \\
\text { cyhalothrin }\end{array}$ & $\begin{array}{c}\text { Phosalo } \\
\text { ne }\end{array}$ & $\begin{array}{l}\text { Flubend } \\
\text { amide }\end{array}$ & $\begin{array}{l}\text { Profen } \\
\text { ophos }\end{array}$ & $\begin{array}{l}\text { Dimet } \\
\text { hoate }\end{array}$ & $\begin{array}{l}\text { Lambda } \\
\text { cyhalothrin }\end{array}$ & \begin{tabular}{|c|} 
Phosa \\
lone
\end{tabular} & $\begin{array}{c}\text { Flubenda } \\
\text { mide }\end{array}$ & $\begin{array}{l}\text { Profen } \\
\text { ophos }\end{array}$ \\
\hline 0 & 0.19 & 0.16 & 4.21 & 0.76 & 2.24 & 0 & 0 & 0 & 0 & 0 \\
\hline 1 & 0.14 & 0.12 & 2.44 & 0.50 & 1.26 & 26.31 & 25 & 42.04 & 34.21 & 43.75 \\
\hline 3 & 0.10 & 0.07 & 1.15 & 0.27 & 0.76 & 47.36 & 56.25 & 72.68 & 66.47 & 66.07 \\
\hline 5 & 0.08 & 0.06 & 0.81 & 0.15 & 0.47 & \begin{tabular}{|l|}
57.89 \\
\end{tabular} & 62.5 & 80.76 & 80.26 & 79.01 \\
\hline 7 & $\overline{B D L}$ & $\overline{B D L}$ & 0.48 & BDL & 0.18 & 100 & 100 & 88.59 & 100 & 91.96 \\
\hline 10 & BDL & BDL & BDL & BDL & BDL & 100 & 100 & 100 & 100 & 100 \\
\hline 15 & $\overline{B D L}$ & $\overline{B D L}$ & BDL & BDL & $\overline{B D L}$ & 100 & 100 & 100 & 100 & 100 \\
\hline 20 & BDL & BDL & BDL & BDL & $\mathrm{BDL}$ & 100 & 100 & 100 & 100 & 100 \\
\hline
\end{tabular}


Table2. Dissipation of different insecticides in Capsicum in poly house

\begin{tabular}{|c|c|c|c|c|c|c|c|c|c|c|}
\hline \multirow{2}{*}{\begin{tabular}{|c|}
$\begin{array}{c}\text { Days after last } \\
\text { spray }\end{array}$ \\
\end{tabular}} & \multicolumn{5}{|c|}{ Residues of different insecticides( $\left.\mathrm{mg} \mathrm{kg}^{-1}\right)$} & \multicolumn{5}{|c|}{ Dissipation \% } \\
\hline & $\begin{array}{c}\text { dimeth } \\
\text { oate }\end{array}$ & $\begin{array}{c}\text { lambda } \\
\text { cyhalothrin }\end{array}$ & $\begin{array}{c}\text { Phosa } \\
\text { lone }\end{array}$ & $\begin{array}{c}\text { Flubenda } \\
\text { mide }\end{array}$ & $\begin{array}{l}\text { Profen } \\
\text { ophos }\end{array}$ & $\begin{array}{l}\text { dimet } \\
\text { hoate }\end{array}$ & $\begin{array}{c}\text { lambda } \\
\text { cyhalothrin }\end{array}$ & $\begin{array}{c}\text { Phos } \\
\text { alone }\end{array}$ & $\begin{array}{l}\text { Flubend } \\
\text { amide }\end{array}$ & $\begin{array}{c}\text { Profeno } \\
\text { phos }\end{array}$ \\
\hline 0 & 2.42 & 0.37 & 5.35 & 1.19 & 3.71 & 0 & 0 & 0 & 0 & 0 \\
\hline 1 & 0.86 & 0.12 & 2.92 & 0.89 & 2.24 & 64.46 & 67.56 & 45.42 & 25.21 & 39.62 \\
\hline 3 & 0.39 & 0.11 & 1.96 & 0.64 & 1.27 & 83.88 & 70.27 & 63.36 & 46.21 & 65.76 \\
\hline 5 & 0.34 & 0.07 & 1.39 & 0.39 & 0.66 & 85.95 & 81.08 & 74.01 & 66.22 & 82.21 \\
\hline 7 & 0.10 & 0.05 & 0.81 & 0.17 & 0.33 & 95.86 & 86.48 & 84.8 & 85.71 & 91.10 \\
\hline 10 & BDL & BDL & 0.50 & 0.14 & 0.17 & 100 & 100 & 90.6 & 88.23 & 95.41 \\
\hline 15 & BDL & BDL & BDL & BDL & BDL & 100 & 100 & 100 & 100 & 100 \\
\hline 20 & BDL & BDL & BDL & BDL & BDL & 100 & 100 & 100 & 100 & 100 \\
\hline
\end{tabular}

\section{REFERENCES}

[1] Thacker, N. P., Bassin, J. K., Nitnaware, V., Vaidya, P., Das, S. K and Biswas, M. 2005. Proceeding of the national seminar on pesticide residues and their risk assessment. 65-77.

[2] Singh, B., Gupta, A., Bhatnagar, A and Parihar, N. S. 1999. Monitoring of pesticide residues in farmgate samples of capsicum. Pesticide Research Journal. 11(2): 207-209.

[3] Central Insecticide Board and Registration Committee. Major uses of pesticides. 20 June 2014. http://www.cibrc.nic.in

[4] Food Safety and Standards Authority of India. Maximum Residue Limits for pesticides on tomato. 19 June 2014. www.fssai.gov.in

[5] Jayakrishnan, S., Dikshit, A. K., Singh, J. P and Pachauri, D. C. 2005. Dissipation of lambdacyhalothrin on tomato (Lycopersicon esculentum Mill.) and removal of its residues by different washing processes and steaming. Bulletin of Environmental Contamination and Toxicology. 75: 324-328.

[6] Natekar, M. G., Rai, S and Agnihotri, N. P. 1988. Bioefficacy of synthetic pyrethroids and their

[7] Ahuja, A. K., Mohapatra, S., Sharma, D and Awasthi, M. D. 2006. Residue persistence of different formulations of lambda cyhalothrin in brinjal. Indian Journal of Plant Protection. 34(1): 122-123.

[8] Reddy, K. N., Satyanarayana, S and Reddy, K. D. 2007. Persistance of some insecticides in capsicumes. Pesticide Research Journal. 19 (2): 234-236.

[9] Rajukkannu, K., Saivaraj, K., Vasudevan, P and Balasubramaian, M. 1979. Residues of phosalone, quinolphos, meth parathion and fenitrothion in on tomato. Indian Journal of Plant Protection. 8(1): 19-21.

[10] Pareek, B. L and Kavadia, V. S. 1990. Residues of some insecticides on round gourd. Indian Journal of Plant Protection. 18: 281-283

[11] Rajukannu, K., Saivaraj, K., Vasudevan, P and Balasubramanian, M. 1980. Residues of certain newer insecticides in brinjal. Pesticides. 5(1): 15-17.

[12] Sahoo, S. K., Sharma, R. K., Battu, R. S and Singh. B. 2009. Dissipation kinetics of flubendiamide on chili and soil. Bulletin of Environmental Contamination and Toxicology. 83: 384-387.

[13] Sharma, B. N and Parihar, N. S. 2013. Dissipation and persistence of flubendiamide and thiacloprid in/on tomato and soil. Bulletin of Environmental Contamination and Toxicology. 90: 252-255.

[14] Kooner, R., Sahoo, S. K., Singh, B and Battu, R. S. 2010. Dissipation kinetics of fluubendiamide and thiacloprid on tomato (Lycopersicon esculentum Mill) and soil. Quality Assurance and Safety of Crops \& Foods. 36-40.

[15] Jyothsna, M., Reddy, D. J., Reddy, C. N and Rahman, S. M. A. S. 2012. Dissipation of flubendiamide, thiacloprid and flubendiamide+thiacloprid on gherkins. Indian Journal of Plant Protection. 40 (2): 133-140

[16] Paramasivam, M and Banerjee, H. 2013. Dissipation of flubendiamide residues in/on cabbage ( Brassica oleracea L). Environmental Monitoring and Assessment. 185: 1577-158. 
[17] Mohapatra, S., Ahuja. A. K., Deepa, M., Sharma, D., Jagadish, G. K and Rashmi, N. 2010. Persistence and dissipation of flubendiamide and des-iodo flubendiamide in cabbage. (Brassica oleracea Linne) and soil. Bulletin of Environmental Contamination and Toxicology. 85: 352356.

[18] Ahmed A. R., Tarek M. M., Rady A. R and Mohamed, Y. H. 2009. Dissipation of Profenofos, Imidacloprid and Penconazole in Tomato Fruits and Products. Bulletin of Environmental Contamination and Toxicology. 83:812-817.

[19] Radwan, M. A., Shiboob, M. M., Elamayem, A and Aal, A. A. 2004. Pirimiphos-methyl residues in some field grown vegetables and removal using various washing solutions and kitchen processing. International Journal of Agriculture and biology. 6(6): 1026-1029.

[20] Gupta, S., Gajbhiye, V. T., Sharma, R. K and Gupta, R. K. 2011. Dissipation of cypermethrin, chlorpyriphos, and profenofos in tomato fruits and soil following application of pre-mix formulations. Environmental Monitoring and Assessment. 174(1): 337-345

[21] Renuka, S., Rajabaskar, D and Regupathy, A. 2006. Persistence and dissipation of profenofos 50 EC in cardamom. Indian Journal of Plant Protection. 34(2): 165-167

[22] Katroju, R., Cherukuri, S. R., Vemuri, S. B and Reddy, N. K. 2014. Dissipation pattern of profenophos in tomato. International Journal of Applied Biology and Pharmaceutical Technology. 5(1): 252-256. 